\title{
Hubungan antara Modal Psikologis dengan Adaptabilitas Karier pada Emerging Adult Terdampak PHK
}

\author{
ZAHRA MAGHFIRA RAMADHANI \& DIMAS ARYO WICAKSONO* \\ Fakultas Psikologi Universitas Airlangga
}

\begin{abstract}
ABSTRAK
Penelitian ini bertujuan untuk mengetahui hubungan antara modal psikologis dengan adaptabilitas karier pada emerging adult yang terdampak PHK di masa pandemi COVID-19. Modal psikologis merupakan kondisi psikologis yang positif pada individu yang dikarakteristikkan ketika seseorang memiliki keyakinan diri, optimisme, harapan, dan resiliensi yang baik. Adaptabilitas karier adalah kesiapan seseorang dalam menghadapi tuntutan peran dan kondisi dunia kerja. Penelitian ini dilakukan pada 262 emerging adult berusia 18-29 tahun yang mengalami PHK di masa pandemi COVID-19. Alat ukur yang digunakan yaitu Career Adaptabilities Scale (CAAS) Form 2.0 dan Compound PsyCap Scale (CPC-12). Analisis data dilakukan dengan teknik korelasi Pearson's $r$ dengan bantuan program Jamovi 1.6.9.0 for Windows. Hasil dari penelitian ini menunjukkan adanya korelasi yang signifikan antara modal psikologis dan adaptabilitas karier $(\mathrm{r}=0,54, \mathrm{p}=<0,001)$. Korelasi bersifat positif yang mana artinya semakin tinggi modal psikologis maka semakin tinggi kemampuan adaptabilitas karier pada emerging adult yang terdampak PHK di masa pandemi COVID-19.
\end{abstract}

Kata kunci: adaptabilitas karier, COVID-19, emerging adult, modal psikologis, PHK

\begin{abstract}
This study aims to determine a relationship between psychological capital and career adaptability on emerging adults who were laid off during the COVID-19 pandemic. Psychological capital is an positive psychological state in individual which characterized by a good self-efficacy, optimism, hope, and resilience. Career adaptability is individual readiness in facing job role demands and working conditions. This research was conducted on 262 emerging adults at the age of 18-29 years who were laid off during the COVID-19 pandemic. The measuring instrument is Career Adaptabilities Scale (CAAS) Form 2.0 and Compound PsyCap Scale (CPC-12). Data was analyzed using Pearson's r correlation technique with Jamovi 1.6.9.0 for Windows. The result shows that there is a positive relationship between psychological capital and career adaptability $(r=0,54, p=<0,001)$ which means that the higher the psychological capital, the higher the career adaptability of emerging adults who were laid off during the COVID-19 pandemic.
\end{abstract}

Keywords: career adaptability, COVID-19, emerging adult, laid off, psychological capital

Buletin Penelitian Psikologi dan Kesehatan Mental (BRPKM), 2021, Vol. 1(1), 810-818

*Alamat korespondensi: Fakultas Psikologi Universitas Airlangga, Kampus B Universitas Airlangga Jalan Airlangga 4-6 Surabaya 60286.Surel: aryo.wicaksono@psikologi.unair.ac.id

Naskah ini merupakan naskah dengan akses terbuka dibawah ketentuan the Creative Common Attribution License (CC-BY-4.0) (http://creativecommons.org/licenses/by/4.0), 
sehingga penggunaan, distribusi, reproduksi dalam media apapun atas artikel ini tidak dibatasi, selama sumber aslinya disitir dengan baik.

\section{PEN D A H U L U A N}

Tahun 2020 memberikan kejutan sekaligus tantangan pada dunia dengan mewabahnya virus COVID19. Kecepatan penyebaran virus ini membuat World Health Organization (WHO) pada tanggal 12 Maret 2020 menetapkan status pandemi. Tujuan dari penetapan status pandemi oleh World Health Organization (WHO) adalah agar setiap negara dapat mempersiapkan strategi untuk melakukan pencegahan serta penanganan (Jannah, 2020). Berdasarkan hal tersebut, maka langkah yang diambil oleh pemerintah Republik Indonesia adalah dengan menerbitkan Peraturan Pemerintah Republik Indonesia No. 21 Tahun 2020 yang mengatur tentang kebijakan Pembatasan Sosial Berskala Besar (PSBB).

Kebijakan tersebut menjadi salah satu protokol kesehatan yang perlu dilakukan untuk menekan laju penyebaran COVID-19. Namun di sisi lain, Pembatasan Sosial Berskala Besar (PSBB) justru memberikan dampak yang cukup buruk bagi perekonomian. Mengutip laman berita daring Kompas (Fauzia, 2020), pada kuartal III-2020 tepatnya di tanggal 5 November 2020 Negara Indonesia resmi masuk ke jurang resesi setelah Badan Pusat Statistik (BPS) melaporkan pertumbuhan produk Domestik Bruto (PDB) minus 3,49 persen secara tahunan. Selanjutnya, pada kuartal I-2021, Menteri Keuangan Sri Mulyani memproyeksi pertumbuhan ekonomi masih berada di zona negatif dan mengalami kontraksi di kisaran minus 1 persen hingga minus 0,1 persen (Fauzia, 2020).

Situasi pandemi saat ini memberi efek domino bagi seluruh sektor dalam kehidupan, termasuk salah satunya adalah meningkatnya angka pengangguran. Menurunnya kegiatan produksi jelas berakibat bagi keberlangsungan perusahaan atau organisasi. Melansir portal berita daring Kumparan (2020), Lembaga Ilmu Pengetahuan Indonesia (LIPI) mencatat terdapat sekitar 39,4\% usaha yang terhenti atau gulung tikar dan $57,1 \%$ usaha mengalami penurunan produksi, hanya 3,5\% saja yang tidak terdampak. Hal ini masih tetap menjadi penyebab utama bagi perusahaan untuk mengambil keputusan pemutusan hubungan kerja di tahun 2021. Mengutip laman Warta Ekonomi (Hidayat, 2021), Ida Fauziyah, Menteri Ketenagakerjaan (Menaker), menyebut terdapat setidaknya 29.120 .000 penduduk usia kerja terdampak pandemi COVID-19 dengan rincian sejumlah 9.770 .000 orang berstatus sebagai pengangguran terbuka. Lebih lanjut, portal berita daring Detik (Kusuma, 2021), menjelaskan apabila dilihat berdasarkan kelompok usia, penduduk kelompok usia muda dari rentang usia 12-24 tahun merupakan kelompok terdampak pemutusan hubungan kerja paling tinggi yaitu mencapai 20,46\% dan rentang usia 25-29 tahun meningkat 5,04\%. Sementara kelompok usia tua yakni 60 tahun ke atas merupakan yang terendah dengan kisaran 1,70\% saja.

Dalam beberapa jurnal ilmiah, angkatan kerja muda dikenal dengan istilah emerging adult (Konstam dkk., 2015; Shulman dkk., 2014). Seseorang yang berada dalam kelompok usia emerging adult ini, merupakan individu yang tergolong dalam rentang usia 18-29 tahun dan memiliki kecenderungan akan ketidakstabilan, optimisme, kebebasan pribadi, kesempatan, fokus diri, dan harapan yang begitu tinggi (Arnett, 2000, 2006; Arnett \& Fishel, 2013 dalam Konstam dkk., 2015). Mereka yang masuk ke dalam kategori perkembangan emerging adult menjadi lebih rentan terhadap tekanan psikologis ketika menyandang status sebagai seorang pengangguran; mereka cenderung merasa tidak terikat atau tanpa jangkar (Bynner dkk., 1997; Konstam, 2014 dalam Konstam dkk., 2015). Sejalan dengan hal tersebut, McKee Ryan dkk. (2005), Paul dan Moser (2009), Price, Choi, dan Vinokur (2002) menjelaskan pula dalam penelitian mereka masing-masing bahwa menjadi seorang pengangguran atau menganggur itu 
merupakan sebuah pengalaman yang membuat stres, menyedihkan, sekaligus memuakkan dan seringkali diasosiasikan dengan peningkatan terhadap kecemasan, depresi, dan perasaan terisolasi (Konstam dkk., 2015). Sehingga, kesehatan mental individu dapat mengalami diskontinuitas dalam periode emerging adulthood karena status pengangguran yang melekat padanya itu.

Sejalan dengan hal tersebut, Konstam dkk. (2015) menyebutkan bahwa adaptabilitas karier merupakan salah satu solusi yang relevan bagi para emerging adult untuk bertahan dan berkembang dalam lingkungan kerja yang menantang (Konstam dkk., 2015), yang mana seseorang dengan tingkat adaptabilitas karier yang tinggi akan lebih mungkin untuk mendapatkan pekerjaan dengan cepat (Koen dkk., 2010). Namun, berdasarkan apa yang ada dalam pemberitaan nasional dapat dikatakan bahwa sampai di tahun 2021 ini, angka pengangguran akibat terdampak Pemutusan Hubungan Kerja (PHK) masih terus ada dan tidak menunjukkan tanda-tanda pengurangan. Penulis menduga bahwa kemungkinan besar kemampuan adaptabilitas karier pada emerging adult belum berkembang dengan sempurna, sehingga angka pengangguran akibat terdampak Pemutusan Hubungan Kerja (PHK) tidaklah berkurang seiring dengan berjalannya waktu. Koen dkk., (2010) menyebut bahwa seseorang dengan kemampuan adaptabilitas karier yang rendah cenderung mudah menyerah dalam usaha pencarian kerja sehingga seringkali berhenti berusaha tepat di tempat mereka baru saja memulai usahanya.

Salah satu variabel yang dapat mendukung pengembangan adaptabilitas karier adalah modal psikologis. Modal psikologis sendiri merupakan kondisi psikologis yang positif pada individu yang dikarakteristikkan ketika seseorang memiliki keyakinan diri, optimisme, harapan, dan resiliensi yang baik (Luthans dkk., 2007). Dalam penelitian yang dilakukan oleh Safavi dan Bouzari (2019) pada karyawan hotel garda depan disebutkan bahwa modal psikologis dengan dimensinya yaitu self-efficacy, resilience, optimism, dan hope, berhubungan positif dengan adaptabilitas karier. Dimana melalui modal psikologis, kapasitas seorang individu untuk dapat menangani tuntutan, tekanan karier di dalam dunia kerja dan kemampuan untuk mengatasi masalah di tempat kerja dapat meningkat. Seorang individu yang demikian menjadi lebih siap untuk organisasi atau perusahaan tempatnya bekerja di masa depan, membuat pilihan yang lebih tepat, mengamati berbagai cara dalam melakukan sesuatu, dan meningkatkan kemampuan mereka dalam pekerjaan (Safavi \& Bouzari, 2019). Yang mana, kesiapan seseorang dalam menghadapi tuntutan dalam peran sebuah pekerjaan dan kondisi kerja merupakan salah satu bentuk dari kemampuan adaptabilitas karier (Savickas, 1997 dalam Koen dkk., 2012).

Kendati demikian, penelitian Safavi dan Bouzari (2019) dilakukan kepada mereka yang telah memiliki pekerjaan yang mana berbeda dengan konteks penelitian yang ingin penulis cari tahu lebih dalam yakni emerging adult terdampak Pemutusan Hubungan Kerja (PHK) pada masa pandemi COVID-19. Oleh karena itu, penulis ingin mencari tahu lebih lanjut apakah hubungan antara modal psikologis dengan adaptabilitas karier benar adanya bahkan jika dikaitkan dengan seseorang yang tidak memiliki pekerjaan sekalipun seperti emerging adult yang terdampak PHK di masa pandemi COVID-19 ini.

\section{Desain Penelitian}

\section{E T O D E}

Penelitian ini menggunakan desain penelitian survei cross-sectional dan pendekatan kuantitatif. Pendekatan ini penulis gunakan dengan tujuan agar menghasilkan data dalam bentuk angka yang didapatkan dari hasil jawaban partisipan melalui survei atau pertanyaan yang diajukan ke sejumlah partisipan dalam kuesioner. Pengumpulan data dilakukan dengan menyebarkan kuesioner atau angket secara daring melalui Google Form. Kuesioner terbagi menjadi empat bagian yaitu demografis, skala Career Adaptabilities Scale (CAAS) Form 2.0 untuk mengukur adaptabilitas karier, Compound PsyCap 
Scale (CPC-12) untuk mengukur modal psikologis, dan skala socioeconomic issue sebagai screening persepsi. Uji validitas yang digunakan yaitu content validity dengan metode Content Validity Index (CVI) berdasarkan penilaian ahli atau professional judgement. Sedangkan pengukuran reliabilitas menggunakan koefisien Alpha Cronbach. Analisis data yang dgunakan yaitu korelasi Pearson dengan bantu perangkat lunak Jamovi 1.6.9.0 for Windows. Analisis data tersebut dipakai dengan tujuan untuk mengetahui hubungan antara modal psikologis dengan adaptabilitas karier pada emerging adult terdampak PHK di masa pandemi COVID-19.

\section{Partisipan}

Partisipan dalam penelitian ini emerging adult, berusia 18-29 tahun dan pernah mengalami PHK (atas kehendak sendiri, habis masa kontrak, efisiensi pekerja, pemecatan akibat melanggar aturan, dll.) di masa pandemi COVID-19. Teknik sampling yang digunakan adalah purposive sampling, merupakan metode pemilihan partisipan penelitian yang sesuai dengan karakteristik yang diharapkan oleh peneliti (Neuman, 2014). Dalam memperkirakan jumlah sampel yang akan diteliti, penulis menggunakan perangkat lunak $G^{*}$ Power dengan statistical power sebesar 0,95 dan effect size sebesar 0,45 maka diperoleh hasil sampel minimal sejumlah 58 partisipan. Sebelum mengisi kuesioner, partisipan diminta untuk membaca informed consent lebih dulu untuk memastikan bahwa partisipan setuju dalam keadaan sadar untuk berpartisipasi dalam penelitian ini.

Penelitian ini melibatkan 262 partisipan $\left(M_{\mathrm{usia}}=23,3 ; S D_{\mathrm{usia}}=2,76 ; 67,9\right.$ persen perempuan $)$. Berdasarkan data demografis didapatkan sebanyak 193 partisipan $(73,7 \%)$ belum mendapatkan pekerjaan kembali. Sementara senyak 69 partisipan (26,3\%) sudah mendapatkan pekerjaan kembali.

\section{Pengukuran}

Pengukuran adaptabilitas karier dalam penelitian ini menggunakan Career Adaptabilities Scale (CAAS) Form 2.0 yang dikembangkan oleh Savickas dan Porfeli (2012) dan diterjemahkan oleh Faadhilah (2016). Skala ini terdiri dari 24 aitem dengan 5 kategori pilihan jawaban (1="lemah", 5="paling kuat"). Kemudian, pengukuran modal psikologis menggunakan Compound PsyCap Scale (CPC-12) yang dikembangkan oleh Lorenz, Beer, Putz, dan Heinitz (2016) dan diterjemahkan oleh Khairurahman (2017). Skala ini terdiri dari 12 aitem dengan 6 kategori pilihan jawaban (1="sangat tidak setuju", 6="sangat setuju"). Sementara untuk screening persepsi, penulis menggunakan skala socioeconomic issue yang dikembangkan oleh Shammi, Bondrud-Doza, Reza, dan Rahman (2020). Skala ini terdiri dari 11 aitem dengan 5 kategori pilihan jawaban (1="sangat tidak setuju", 5="sangat setuju").

Validitas yang digunakan yaitu validitas isi (content validity) dengan metode Content Validity Index (CVI) berdasarkan penilaian ahli atau professional judgement yang dianggap memiliki keahlian sesuai dengan bidang penelitian ini. Pada penelitian ini didapat nilai CVI untuk Career Adaptabilities Scale (CAAS) Form 2.0 sebesar 1. Sementara untuk Compound PsyCap Scale (CPC-12) didapatkan nilai CVI sebesar 0,979. Kemudian, berdasarkan penelitian yang telah dilakukan sebelumnya, reliabilitas alat ukur CAAS adalah coefficient $\alpha=0,943$ dan CPC-12 adalah coefficient $\alpha=0,757$. Namun, apabila dilihat dari data yang telah dikumpulkan penulis, hasil analisis reliabilitas skala CAAS memiliki reliabilitas sebesar $\alpha=0,926$ dan skala CPC-12 sebesar $\alpha=0,785$.

Pemerolehan skor didapatkan dengan cara menjumlah total jawaban setiap partisipan. Uji asumsi yang dilakukan yaitu uji normalitas yang mana hal ini dilakukan untuk mengetahui apakah data dalam penelitian ini berdistribusi secara normal ataukah tidak. Uji normalitas dilakukan dengan memperhatikan nilai skewness yang mana data dikatakan normal apabila mendekati angka 0 dengan angka - 1 hingga 1 sebagai batas maksimum dan nilai kurtosis yang mana data dikatakan normal apabila mendekati angka 0 dengan angka -2 hingga 2 sebagai batas maksimum (Navarro \& Foxcroft, 2019). 
Dalam penelitian ini didapatkan nilai skewness sebesar -0,82 dan kurtosis sebesar 1,54 untuk variabel adaptabilitas karier, serta nilai skewness sebesar 0,29 dan kurtosis sebesar -0,02 untuk variabel modal psikologis, sehingga dapat dikatakan bahwa keduanya memenuhi asumsi normalitas.

\section{Analisis Data}

Analisis data yang dilakukan penulis adalah uji korelasi Pearson untuk melihat hubungan antara modal psikologis dan adaptabilitas karier. Selain itu, dilakukan pula uji beda menggunakan independent $t$-test untuk melihat perbedaan tingkat adaptabilitas karier apabila ditinjau dari segi status sudah atau belumnya partisipan mendapatkan pekerjaan kembali, latar belakang pendidikan, dan jenis kelamin. Seluruh analisis statistik dilakukan dengan bantuan perangkat lunak Jamovi 1.6.9.0 for Windows.

\section{HAS IL P EN EL I T IA N}

Hasil analisis deskriptif menunjukkan sebagian besar partisipan memiliki kemampuan adaptabilitas karier kategori sedang, yaitu sebanyak 101 orang (38,55\%). Sedangkan partisipan penelitian yang memiliki kemampuan adaptabilitas karier kategori sangat rendah sebanyak 17 orang $(6,49 \%)$, kategori rendah sebanyak 52 orang (19,85\%), dan partisipan yang memiliki kemampuan adaptabilitas karier kategori sangat tinggi sebanyak 14 orang (5,34\%) dan kategori tinggi sebanyak 78 orang (29,77\%). Selain itu, sebagian besar partisipan dalam penelitian ini memiliki tingkatan modal psikologis kategori sedang, yaitu sebanyak 91 orang $(34,73 \%)$. Sementara partisipan yang memiliki tingkatan modal psikologis kategori sangat rendah sebanyak 17 orang (6,49\%), kategori rendah sebanyak 63 orang $(24,05 \%)$, dan partisipan yang memiliki tingkatan modal psikologis kategori sangat tinggi sebanyak 19 orang $(7,25 \%)$ dan kategori tinggi sebanyak 72 orang $(27,48 \%)$.

Hasil analisis korelasi diketahui bahwa modal psikologis berkorelasi positif dan kuat dengan adaptabilitas karier $(\mathrm{r}(262)=0,547,95 \%$ CI $[0,626 ; 0,456], \mathrm{p}=<0,001)$. Selain itu, penulis melakukan analisis independent $t$-test untuk menguji ada tidaknya perbedaan kemampuan adaptabilitas karier pada emerging adult yang telah mendapatkan pekerjaan kembali $(N=69 ; M=101 ; S D=11,5)$ dengan yang belum mendapatkan pekerjaan kembali $(N=193 ; M=100 ; S D=12,9)$, hasil menunjukkan tidak ada perbedaan $(\mathrm{t}(260)=0,364 ; p=0,642$; Cohen's $d=0,005 ; 95 \%$ CI [-Inf; $-1,43])$. Begitu pula dengan analisis independent $t$-test pada emerging adult dengan latar belakang pendidikan terakhir perguruan tinggi $(N=135 ; M=102 ; S D=11,3)$ dan SMA/sederajat $(N=127 ; M=97,8 ; S D=13,4)$, hasil menunjukkan tidak ada perbedaan $(\mathrm{t}(260)=3,04 ; p=0,999 ;$ Cohen's $d=0,376 ; 95 \%$ CI $[-$ Inf; 7,16]). Sementara analisis independent $t$-test berdasarkan jenis kelamin, pada emerging adult perempuan $(N=178 ; M=102$; $S D=11,5)$ dan laki-laki $(N=84 ; M=97,4 ; S D=14,1)$, hasil menunjukkan terdapat perbedaan tingkat adaptabilitas karier $(\mathrm{t}(260)=-2,52 ; p=0,006$; Cohen's $d=-0,334 ; 95 \%$ CI [-Inf; -143$])$.

\section{I S K U S I}

Uji korelasi menunjukkan adanya hubungan yang signifikan di antara kedua variabel penelitian sehingga dapat diambil kesimpulan bahwa Ho ditolak. Kekuatan korelasi antara kedua variabel tersebut adalah tinggi sedangkan berdasarkan arahnya, hubungan antara modal psikologis dan adaptabilitas karier adalah positif yang mana artinya semakin tinggi modal psikologis maka semakin tinggi pula adaptabilitas karier. Tidak ada perbedaan yang siginifikan pada adaptabilitas karier apabila ditinjau dari segi status sudah atau belumnya partisipan mendapatkan pekerjaan kembali dan latar belakang pendidikan. Namun, berdasarkan jenis kelamin ditemukan adanya perbedaan tingkat adaptabilitas karier. 
Hasil penelitian ini selaras dengan penelitian yang telah ada sebelumnya. Safavi dan Bouzari (2019) melalui penelitiannya menemukan bahwa terdapat hubungan positif yang signifikan antara modal psikologis dengan adaptabilitas karier. Hal ini bisa jadi terjadi karena melalui modal psikologis, kapasitas seorang individu untuk dapat menangani tuntutan, tekanan karier di dalam dunia kerja dan kemampuan untuk mengatasi masalah di tempat kerja dapat meningkat. Akibatnya, seorang individu yang demikian menjadi lebih siap untuk organisasi atau perusahaan tempatnya bekerja di masa depan, membuat pilihan yang lebih tepat, mengamati berbagai cara dalam melakukan sesuatu, dan meningkatkan kemampuan mereka dalam pekerjaan (Safavi \& Bouzari, 2019).

Selain itu Pajic dkk. (2018) dalam penelitiannya mengenai imigran pencari kerja, menemukan pula bahwa modal psikologis berhubungan positif dengan dengan job search self-efficacy melalui adaptabilitas karier. Atau dengan kata lain keempat dimensi dari modal psikologis yakni self-efficacy, hope, resilience, dan optimism berhubungan positif dengan adaptabilitas karier, namun pada penelitian ini hubungan di antara keduanya dimoderasi oleh social career barrier atau hambatan sosial karier. Yang mana berarti, keyakinan atas diri sendiri, harapan, resiliensi, dan optimisme, dimensi dari modal psikologis ini dapat membuat seorang individu memiliki kemampuan adaptabilitas karier yang lebih baik. Sehingga, seseorang menjadi lebih yakin pula dalam mencari pekerjaan di negara tujuan, dan sebagai tambahan bahwa kemampuan adaptabilitas karier seseorang akan melemah atau menguat sesuai dengan hambatan sosial karier yang dirasakan. Apabila hambatan sosial karier yang dirasakan cenderung kecil, maka hubungan antara modal psikologis dengan adaptabilitas karier akan lebih kuat dibandingkan ketika hambatan sosial karier yang dirasakan oleh seorang individu lebih tinggi. Dalam hal ini, hambatan sosial karier diartikan sebagai peristiwa atau kondisi baik dalam internal maupun eksternal atau lingkungan seorang individu yang membentuk hambatan bagi kemajuan karier (Swanson \& Woitke, 1997 dalam Pajic dkk., 2018). Bukan tidak mungkin apabila seseorang mengalami banyak hambatan sepanjang kariernya. Apabila dikaitkan dengan para imigran pencari kerja, kemungkinan hambatan sosial karier yang akan mereka hadapi adalah seperti keterampilan bahasa yang kurang memadai, kualifikasi pekerjaan yang tidak dapat dialihkan, perbedaan budaya, sampai dengan kendala hukum terkait pekerjaan sebelum mendapatkan izin tinggal (Shekhar, dkk., 2016 dalam Pajic dkk., 2018).

Berdasarkan paparan sebelumnya, peneliti dapat menyimpulkan bahwa terjadinya hubungan yang kuat antara variabel modal psikologis dan adaptabilitas karier dapat pula dipengaruhi oleh berbagai faktor atau variabel lainnya seperti hambatan sosial karier yang dirasakan oleh masing-masing individu. Dalam hal ini, kemungkinan besar partisipan yang terlibat dalam penelitian ini merasakan hambatan sosial karier yang cenderung sedikit meski berada di tengah-tengah situasi krisis akibat pandemi. Kendati demikian, hasil screening persepsi socioeconomic issue menunjukkan bahwa mayoritas partisipan yang terlibat dalam penelitian ini dipengaruhi oleh pandemi COVID-19. Sedikit bertentangan dengan apa yang idealnya terjadi namun mengacu pada Wilkins dkk., (2014) adaptabilitas karier memungkinkan seseorang untuk dapat berkembang di tengah-tengah kondisi stres atau situasi sulit. Sehingga adapun hal-hal yang seharusnya membuat emerging adult merasakan hambatan sosial karier yang begitu hebat seperti "Banyak orang akan kehilangan pekerjaannya saat pandemi COVID-19 ini" dan tekanan lain seperti atau "Harga kebutuhan bahan pokok saat ini melonjak karena pandemi COVID19" dapat ditangani dan dimaknai dengan baik. Hal ini dapat dibuktikan melalui mayoritas partisipan yang berada pada kategorisasi sedang untuk adaptabilitas karier dan modal psikologis. 


\section{S I M P U L A N}

Hasil temuan dalam penelitian ini menunjukkan adanya hubungan antara modal psikologis dan adaptabilitas karier. Kekuatan korelasi antara kedua variabel tersebut adalah tinggi, sehingga dapat diartikan bahwa modal psikologis memberikan dampak yang besar terhadap adaptabilitas karier pada emerging adult yang terdampak PHK di masa pandemi COVID-19. Sedangkan berdasarkan arahnya, hubungan di antara kedua variabel tersebut yakni berarah positif, yang mana berarti semakin tinggi tingkat modal psikologis seseorang maka semakin tinggi pula tingkat adaptabilitas karier yang ada pada diri seorang individu. Hal ini juga berlaku sebaliknya, semakin menurun tingkat modal psikologis seseorang maka semakin menurun pula tingkat adaptabilitas karier yang ada pada diri seorang individu.

Hasil penelitian ini kemudian dapat menjadi pertimbangan bagi perusahaan untuk melakukan Psychological Capital Intervention pada karyawan. Intervensi tersebut dapat pula dilakukan melalui aktivitas kerja sehari-hari misalnya seperti memberi tugas-tugas dengan tingkat kesulitan yang bertahap atau progresif pada karyawan untuk meningkatkan efikasi diri. Selain itu, bagi emerging adult sendiri diharapkan pula untuk dapat melakukan pengembangan terhadap modal psikologisnya dengan cara seperti percaya atas kemampuan diri sendiri dalam menjalankan tugas, melihat segala situasi yang terjadi dengan realistis, memandang peristiwa buruk yang dihadapi sebagai sesuatu yang sementara, dan segera bangkit menuju titik normal setelah menghadapi kegagalan, konflik, maupun kejadian positif yang menambah tanggung jawab. Sementara untuk penelitian selanjutnya diharapkan dapat memperhatikan faktor lain sebagai variabel yang mungkin berhubungan dengan kedua variabel penelitian ini. Sebaiknya juga dapat menggali data demografis dengan lebih terperinci sehingga informasi penting seperti masa lama menganggur pasca mengalami Pemutusan Hubungan Kerja (PHK) dan intensi untuk mencari pekerjaan kembali atau tidak dapat diketahui secara jelas. Hal ini dilakukan untuk menghindari adanya faktor-faktor yang tidak diinginkan dan riskan dalam menaikkan tingkatan salah satu variabel.

\section{U C A P A N T ERIMAKASIH}

Terima kasih saya ucapkan kepada Allah SWT, keluarga, teman-teman, dan berbagai pihak yang telah memberi dukungan dan membantu penulis selama proses penelitian.

\section{DEKLARASI POTENSI TERJADINYA KONFLIK KEPENTINGAN}

Zahra Maghfira Ramadhani dan Dimas Aryo Wicaksono tidak bekerja, menjadi konsultan, memiliki saham, atau menerima dana dari perusahaan atau organisasi manapun yang mungkin akan mengambil untung dari diterbitkannya naskah ini.

\section{PUST AKA ACUAN}

Arnett, J. J. (2000). Emerging adulthood: A theory of development from the late teens through the twenties. American Psychologist, 55(5), 469.

Arnett, J. J. (2006). Emerging Adulthood: Understanding the New Way of Coming of Age.

Bynner, J., Ferri, E., \& Shepherd, P. (1997). Changing lives in the 1990s. Twenty-Something in the 1990s: Getting On, Getting By, Getting Nowhere. 
FAADHILAH, A. M. (2016). HUBUNGAN ANTARA LEARNING GOAL ORIENTATION DENGAN ADAPTABILITAS KARIR (CAREER ADAPTABILITY) PADA MAHASISWA TINGKAT AKHIR JURUSAN SASTRA JEPANG UNIVERSITAS AIRLANGGA. Universitas Airlangga.

Fauzia, M. (2020, Maret 26). Indonesia Resmi Resesi, Ekonomi Kuartal III-2020 Minus 3,49 Persen. Dipetik 26 Maret, 2020 dari Kompas Money: https://money.kompas.com/read/2020/11/05/111828826/indonesia-resmi-resesi-ekonomikuartal-iii-2020-minus-349-persen?page=all

Hidayat, F. (2021, Maret 13). Pandemi Bikin 29 Juta Penduduk Usia Kerja Di-PHK. Dipetik 13 Maret, 2021, dari Warta Ekonomi: https://www.wartaekonomi.co.id/read327242/pandemi-bikin-29-jutapenduduk-usia-kerja-di-phk

Jannah, M. (2020). Dampak Psikologis Pandemi Coronavirus Disease (Covid-19) pada Masyarakat Umum di Indonesia. Universitas Muhammadiyah Malang.

KHAIRURAHMAN, M. H. (2017). HUBUNGAN ANTARA PSYCHOLOGICAL CAPITAL DENGAN SELFPERCEIVED EMPLOYABILITY PADA MAHASISWA VOKASI UNIVERSITAS AIRLANGGA. UNIVERSITAS AIRLANGGA.

Koen, J., Klehe, U.-C., \& Van Vianen, A. E. M. (2012). Training career adaptability to facilitate a successful school-to-work transition. Journal of Vocational Behavior, 81(3), 395-408.

Koen, J., Klehe, U.-C., Van Vianen, A. E. M., Zikic, J., \& Nauta, A. (2010). Job-search strategies and reemployment quality: The impact of career adaptability. Journal of Vocational Behavior, 77(1), 126-139.

Konstam, V., Celen-Demirtas, S., Tomek, S., \& Sweeney, K. (2015). Career adaptability and subjective well-being in unemployed emerging adults: A promising and cautionary tale. Journal of Career Development, 42(6), 463-477.

Kumparan. (2020, Mei 23). LIPI: 39,4\% Bisnis di Indonesia Gulung Tikar Akibat Pandemi Corona. Dipetik 23 Mei, 2020, dari Kumparan: https://kumparan.com/kumparansains/lipi-39-4-bisnis-diindonesia-gulung-tikar-akibat-pandemi-corona-1tRdz3TxOQd

Kusuma, H. (2021, Maret 13). Setahun Corona, Angka Pengangguran Nyaris 10 Juta Orang. Dipetik 13 Maret, 2021, dari Detik Finance: https://finance.detik.com/berita-ekonomi-bisnis/d5477342/setahun-corona-angka-pengangguran-nyaris-10-juta-orang

Lorenz, T., Beer, C., Pütz, J., \& Heinitz, K. (2016). Measuring psychological capital: Construction and validation of the compound PsyCap scale (CPC-12). PloS One, 11(4), e0152892.

Luthans, F., Avolio, B. J., Avey, J. B., \& Norman, S. M. (2007). Positive psychological capital: Measurement and relationship with performance and satisfaction. Personnel Psychology, 60(3), 541-572.

McKee-Ryan, F., Song, Z., Wanberg, C. R., \& Kinicki, A. J. (2005). Psychological and physical well-being during unemployment: a meta-analytic study. Journal of Applied Psychology, 90(1), 53.

Navarro, D., \& Foxcroft, D. (2019). Learning statistics with jamovi: A tutorial for psychology students and other beginners (Version 0.70). Tillgänglig Online: Http://Learnstatswithjamovi. Com [Hämtad 14 December].

Neuman, W. (2014). Social Research Methods: Qualitative and Quantitative Approaches Seventh Edition. Pearson Education Limited. 
Pajic, S., Ulceluse, M., Kismihók, G., Mol, S. T., \& den Hartog, D. N. (2018). Antecedents of job search selfefficacy of Syrian refugees in Greece and the Netherlands. Journal of Vocational Behavior, 105, 159172.

Paul, K. I., \& Moser, K. (2009). Unemployment impairs mental health: Meta-analyses. Journal of Vocational Behavior, 74(3), 264-282.

Price, R. H., Choi, J. N., \& Vinokur, A. D. (2002). Links in the chain of adversity following job loss: how financial strain and loss of personal control lead to depression, impaired functioning, and poor health. Journal of Occupational Health Psychology, 7(4), 302.

Safavi, H. P., \& Bouzari, M. (2019). The association of psychological capital, career adaptability and career competency among hotel frontline employees. Tourism Management Perspectives, 30. https://doi.org/10.1016/j.tmp.2019.02.001

Savickas, M. L., \& Porfeli, E. J. (2012). Career Adapt-Abilities Scale: Construction, reliability, and measurement equivalence across 13 countries. Journal of Vocational Behavior, 80(3), 661-673.

Shulman, S., Vasalampi, K., Barr, T., Livne, Y., Nurmi, J.-E., \& Pratt, M. W. (2014). Typologies and precursors of career adaptability patterns among emerging adults: A seven-year longitudinal study. Journal of Adolescence, 37(8), 1505-1515.

Wilkins, K. G., Santilli, S., Ferrari, L., Nota, L., Tracey, T. J. G., \& Soresi, S. (2014). The relationship among positive emotional dispositions, career adaptability, and satisfaction in Italian high school students. Journal of Vocational Behavior, 85(3), 329-338. 